\title{
İnsan Hakları, Yurttaşlık ve Demokrasi Dersini Öğretmenler ve Öğrenciler Nasıl Algılıyor?
}

\section{How Do Teachers and Students Perceive Human Rights, Citizenship and Democracy Course?*}

\author{
Nur Leman BALBAĞ $\breve{G}^{* *}$ Ömür GÜRDOĞAN BAYIR ${ }^{* \star *} \quad$ Arife Figen ERSOY ${ }^{* \star * *}$
}

Öz. "Insan Hakları, Yurttaşlık ve Demokrasi” dersi 2015-2016 öğretim yılından itibaren uygulamaya konulan, ilkokul 4. sınıflarda öğrencilere insan hakları, yurttaşlık ve demokrasi ile ilgili temel değerleri kazandırmayı amaçlayan bir derstir. $\mathrm{Bu}$ araştırmanın amacı, "Insan hakları, yurttaşlık ve demokrasi" dersine ilişkin öğrenci ve öğretmenlerin deneyim ve algılarını irdelemektir. Araştırmada nitel araştırma yöntemı kapsamında olgu bilim deseni benimsenmiştir. Araştırmanın katılımcıları maksimum çeşitlilik örneklemesi tekniği ile belirlenmiştir. Bu kapsamda, araştırma Eskişehir il merkezinde yer alan alt, orta ve üst sosyoekonomik düzeyden öğrencilerin öğrenim gördüğü üç ilkokulda 8 öğretmen ve 20 öğrenci ile gerçekleştirilmiştir. Araştırmanın verileri yarı yapılandırılmış görüşme tekniği ile toplanmıştır. Verilerin analizinde tematik analizden yararlanılmıştır. Araştırma sonucunda, öğrencilerin dersi temel demokratik değerleri çoğunlukla kazandığı için işlevsel olarak algıladığı, sadece öykülere dayalı bir öğretim modeli benimsenmesi nedeniyle Türkçe dersi gibi algıladığı, geleneksel değerlendirme tekniklerinin öğrencilerin demokratik değer kazanımlarını ölçmede yetersiz kaldığı görülmektedir. Bu dersin işlevselliğinin artırılması için, dersin öğretim programı içeriğinin yenilenmesinin yanı sıra ders kitabının yenilenmesi ve ders materyallerinin geliştirilmesi, etkin öğretim yöntemlerinin işe koşulması ve öğretmenlerin bilgilendirilmesi gerekli olduğu görülmektedir.

Anahtar Kelimeler: İnsan hakları, yurttaşlık, demokrasi, ilkokul, olgu bilim.

Abstract. "Human Rights, Citizenship and Democracy" is a course that began to be delivered as of the 2015-2016 school year and aims to teach elementary fourth graders the basic values related to human rights, citizenship and democracy. The aim of this study was to examine students and teachers' experiences and perceptions of the course "Human Rights, Citizenship and Democracy". In the study, phenomenological research design was adopted in the scope of the qualitative research method. The participants were selected through the maximum diversity sampling technique. In this respect, the study was conducted with eight teachers and 20 students in three elementary schools where students with low, middle and high socio-economic status study in the Eskisehir province. The data were gathered by using the semi-structured interview technique. Thematic analysis was employed in the analysis of the data. As a result, it was found that the students perceived the course as functional since they mostly learned basic democratic values, they also perceived it as the Turkish course because an instructional model based on stories was mostly adopted, and traditional assessment techniques were insufficient in measuring students' gains regarding democratic values. In order to enhance the effectiveness of this course, it seems necessary to update the contents of the course curriculum as well as the coursebook, develop course materials, employ effective instructional methods, and inform teachers in this regard.

Keywords: Human rights, citizenship, democracy, primary education, phenomenology.

\footnotetext{
*Bu makale III. Avrasya Eğitim Araştırmaları kongresinde sunulmuş bildirinin genişletilmiş halidir. ** Arş. Gör. Dr., Uşak Üniversitesi Eğitim Fakültesi, Sınıf Eğitimi Anabilim Dalı, nurleman.goz@usak.edu.tr

*** Yrd. Doç. Dr., Anadolu Üniversitesi Eğitim Fakültesi, Sınıf Öğretmenliği Programı, ogurdogan@anadolu.edu.tr

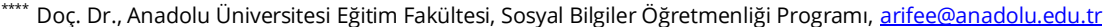




\section{GíRiş}

Eğitim sürecinde nitelikli bireylerin yetiştirilmesi ve toplumların kalkınması etkili vatandaşların yetiştirilmesi ile yakından ilişkilidir. Bu nedenle, planlı eğitim etkinliklerinin yürütüldügü okullarda vatandaşlık eğitimine önem verilmesi gerekmektedir. Vatandaşlık eğitiminin etkili ve güçlü verilmesi sürdürülebilir gelişmenin de temel dayanağıdır. Alanyazında vatandaşlık eğitiminin güçlü ve sürdürülebilir demokrasi için önemli olduğu vurgulanmaktadır (Patrick, 1999; Acun ve diğerleri, 2010).

Vatandaşıık eğitimi vatandaşlık bilgi, beceri ve değerlerinin öğrencilere kazandırıldığı bir eğitim sürecini kapsar (Ersoy, 2007). Etkili bir vatandaşlık eğitimi sonrasında bireyler, adalet, eşitlik, özgürlük, hak, sosyal katılım gibi sosyal ve siyasal kavramları, vatandaşlık hakları ve sorumluluklarını, ulusal ve küresel siyasal ve sosyal kurumların işleyişi ve yapısını ve yerel, ulusal ve küresel sorunları bilir, iletişim, problem çözme, karar verme, eleştirel düşünme gibi bilişsel yeterlikler ile gönüllü kuruluşlarda çalışma gibi katılım yeterliklerine sahip olmaktadır. Ayrıca bireyler bu eğitim sonrasında eşitliğe, insan haklarına, özgürlüğe, saygı ve hoşgörüye, dayanışmaya inanmaktadırlar (Branson, 1998; The Center for Civic Education [CCE], 1997). Vatandaşlık eğitimi sonrasında bu yeterliklere sahip olan bireyler, öncelikle kendilerini nasıl yöneteceklerini öğrenmektedirler. Demokratik bir toplumda bu halk yönetiminin ilk aşamasıdır. Dolayısıyla vatandaşlık eğitimi demokratik toplumlarda öncelikle vatandaşların bir toplum içinde kendilerini nasıl yönetebileceklerinin eğitimidir. Demokratik ülkelerde vatandaşlık eğitimi etkin vatandaşlık eğitimi olarak tanımlanmaktadır. Etkin vatandaşlık demokratik toplumlarda vatandaşın siyasal ve sosyal yaşama etkin katılımını temel almaktadır.

Resmi olarak vatandaşlık eğitimi okullarda, öğretim programı, öğretim programı dışındaki etkinlikler ve örtük program gibi yollarla verilmektedir (Birzéa ve diğerleri, 2004). Öğretim programları, sınıfta öğrencilere vatandaşlık bilgi ve becerilerinin planlı ve programlı bir biçimde kazandırılı̆̆ı süreci kapsamaktadır. Aynı zamanda etkili bir vatandaşlık eğitiminde öğrenme öğretme sürecinin nasıl yapılandırıldı̆̆ konusunda önem taşımaktadır. Alanyazında vatandaşlık eğitimi etkinliklerinin, öğrencilerin yaparak öğrenme sağlayacağı, tartışma ve görüş alışverişine dayalı, yaşamda karşılaşılan sorunlarla ilgili, düsünme becerilerinin kullanıldığı, isbirligine dayalı ve ögrencilerin öğrenme sürecinde söz hakkı olacağı biçimde yapılandırılması (DfES, 2004; Acun ve diğerleri, 2010), sınıf, okul ve okul dışında etkin ve uygulamalı olarak yürütülmesi gerektiği belirtilmektedir (Ersoy, 2014)

Türkiye'de vatandaşlık eğitiminde yıllara göre farklı uygulamalar yapılmıştır. 2005 öğretim yılında uygulanan yeni ilköğretim programı öncesinde vatandaşlık eğitimi "Vatandaşlık ve Insan Hakları" adıyla bir ara disiplin olarak kabul edilmiştir. Böylece her derste öğretmenlerin dersin kazanımları ile vatandaşıı, demokrasi ve insan hakları konularını ilişkilendirilmesi istenmiştir. Ayrıca, 2011-2012 öğretim yılında 8. sınıflarda öğretime başlanan "Vatandaşlık ve İnsan Hakları Eğitimi" dersi okutulmaya başlanmış ve 2016 yılında kaldırılarak 4. sınıflara 2015-2016 yılında "insan hakları, Yurttaşlık ve Demokrasi" adıyla ayrı bir ders konulmuştur.

"Insan Hakları, Yurttaşlık ve Demokrasi” dersi 4. sınıflarda öğrencilere kavramsal bilginin öğretilmesinin yanında; insan hakları, yurttaşıı ve demokrasi ile ilgili temel değerleri kazandırmayı amaçlayan bir derstir. Dersin bir diğer amacı da öğrencilerin bu bilgi ve değerleri bir yaşam biçimi ve kültür hâline getirmelerini sağlamaktır. Insan hakları, Yurttaşlık ve Demokrasi dersi içeriğinde evrensel değerleri dikkate alan "insan merkezlilik", "aktif yurttaşlık", "barış", "uzlaşı", "çoğulculuk", "birlikte yaşama", "çeşitlilik", "hukukun üstünlüğü" gibi konular öne çıkmaktadır. Programın temel yaklaşımında kendine, diğerlerine ve bizim olana ifadeleri vurgulanmıştır. Öğretim programı; (1) İnsan Olmak, (2) Hak, Özgürlük ve Sorumluluk, (3) Adalet ve Eşitlik, (4) Uzlaşı, (5) Kurallar ve (6) Birlikte Yaşama olmak üzere altı üniteden oluşmaktadır. Programda öğretmenlerin konuları öyküler yoluyla işlemeleri istenmiştir (MEB, 2016). 


\subsection{Amaç}

Bu araştırma, ilköğretim programına 2015-2016 öğretim yılında 4. sınıflara konulan “insan hakları, Yurttaşlık ve Demokrasi" dersinin işlevselliğinin öğretmen ve öğrenci görüşlerine dayalı olarak irdelenmesini amaçlamaktadır.

\subsection{Problem}

Türkiye vatandaşlık ve demokrasi eğitimine ilişkin yapılan çalışmalarda vatandaşlık eğitiminin erken yaşlardan başlayarak verilmesi (Güven, Tertemiz ve Bulut, 2009), ders programların içeriğinin yetersiz olduğu (Ersoy, 2014; Ersoy, 2016; Gürdoğan Bayır, Göz ve Bozkurt, 2014) öğrencilerin vatandaşlık yeterliklerini yeterli düzeyde kazanamadıkları (Arıkan, 2002; Güdücü, 2008; Ersoy, 2014; Karaman Kepenekçi, 2005) geleneksel öğretmen merkezli eğitim verildiği, öğretmenlerin vatandaşlık eğitiminde zorlandıkları (Basaran, 2007; Ersoy, 2007; Ersoy, 2014; Güven ve Şahin, 2010; Taş, 2010; Ülger, 2012; Yigittir, 2007), sosyo-kültürel çevrenin olumsuz etkilediği (Ersoy, 2012; Basturk, 2011; Kaya ve Ersoy, 2014; Uyangör, 2007; Tarman ve Kuran, 2014, Toraman, 2012), demokratik okul kültürünün yeterli olmadığı (Ersoy, 2014) sonuçlarına ulaşılmıştır. Ayrıca, ilköğretim programındaki vatandaşlık ve insan hakları ara disiplini üzerine yapılan birçok çalışma bu ara disiplinin işlevsel olmadığını ortaya koymuştur (Bağlı, 2013, Elkatmış, 2012).

Alanyazında bu derse ilişkin yapılan çalışmaların oldukça az oluğu görülmektedir. Sağlam ve Hayal'in (2015) "Insan Hakları, Yurttaşlık ve Demokrasi" dersinin 4. sınıflarda okutulmasına iliş̧kin sınıf öğretmenlerinin görüşlerini aldığı çalışmasında vatandaşlık eğitiminin yalnızca 4. sınıfta verilmesinin öğrencilerin vatandaşlık yeterliklerini kazanmalarında sınırlı olacağı görüşü ortaya çıkmıştır. Ulusoy ve Erkuş’un (2016) "Insan Hakları, Yurttaşlık ve Demokrasi” dersine ilişkin sınıf ve sosyal bilgiler öğretmenlerinin görüşleri aldığı araştırmada ise öğretmenlerin bir kısmının dersin 4. sınıflarda okutulmasına olumlu bakarken, bir kısmının ise olumsuz baktığı ve 5. sınıflarda okutulmasının daha uygun olduğunu düşündüğü ortaya çıkmıştır. Kaymakçı ve arkadaşları (2015) tarafından yapılan Kayseri ve Trabzon illerinde görev yapan ilkokul öğretmeni ve idarecilerine anket uyguladığı araştırmanın sonucunda, bazı öğretmenlerin dersi gerekli görürken bazılarının gerekli görmediği, dersin öğrencilerin demokratik tutum ve davranış gelişimini olumlu etkilediği, birlikte yaşama kültürünü geliştirdiği, derste öğrencilerin temel haklarını öğrendiği, sosyal adalet duygusunu geliştirdiği yönünde sonuçlara ulaşılmıştır. Ancak, 2015-2016 yılında uygulamaya konan bu dersin işlevselliğini farklı bölge ve koşullara göre irdeleyecek çalışmalara gereksinim olduğu alandaki çalışmaların azlığı sonucunda ortaya çıkmıştır. Bu araştırmanın "Insan Hakları, Yurttaşlık ve Demokrasi" dersi konusunda Eskişehir'de farklı sosyo-ekonomik düzeylerdeki okullardaki öğretmen ve öğrencilere ulaşarak alana katkı sağlayacağı düşünülmektedir. Bu araştırma sonuçlarının, ilkokul "Insan Hakları, Yurttaşlık ve Demokrasi" dersi öğretim programlarının geliştirilmesine katkı sağlayacağı umulmaktadır.

\section{YÖNTEM}

Araştırma nitel araştırma yöntemi benimsenerek gerçekleştirilmiştir. Araştırmada nitel araştırma desenlerinden olgu bilim deseninden yararlanılmıştır. Olgu bilim bireylerin kendi bakış açısıyla algı ve deneyimlerini ortaya koymayı amaçlayan bir araştırma desenidir (Lester, 1999'dan akt: Ersoy, 2016). Bu kapsamda araştırmada sınıf öğretmenlerinin ve öğrencilerin derste yaşadıkları deneyimlerden yola çıkarak derse ilişkin görüşleri belirlenmeye çalışıldığı için olgu bilim deseninden yararlanılmıştır.

\subsection{Katılımcılar}

Araştırmanın katılımcıları maksimum çeşitlilik örneklemesi tekniği ile belirlenmiştir. Maksimum çeşitlik örneklemesi, araştırma yapılan alanların ve katılan bireylerin çeşitliliğine dayanmakta ve büyük bir gruptan birçok kişiyi yansıtabilme olanağı vermektedir. Bu kapsamda, araştırma Eskişehir il merkezinde yer alan alt, orta ve üst sosyoekonomik düzeyden öğrencilerin öğrenim gördüğü üç ilkokulda gerçekleştirilmiştir. Bu araştırmaya toplam 8 öğretmen ile 20 öğrenci katılmıştır. 
Araştırmada öğretmen ve öğrencilere kod isimler verilmiştir. Araştırmaya katılan öğrencilerin ve öğretmenlerin kişisel özellikleri tabloda verilmiştir.

Tablo 1. Öğrencilerin Kişisel Özellikleri

\begin{tabular}{lccccc}
\hline Kod isim & Okulun SED & Yaş & Anne meslek & Baba meslek & Doğum yeri \\
\hline Yavuz & Alt & 9 & Memur & Müdür & Eskişehir \\
Fatoş & Alt & 11 & Ev hanımı & İşçi & Eskişehir \\
Ali & Alt & 11 & İşçi & İşçi & Burdur \\
Sevgi & Alt & 10 & Ev hanımı & İşçi & Eskişehir \\
Reyhan & Alt & 10 & Ev hanımı & İşçi & Ankara \\
Öykü & Alt & 10 & Ev hanımı & İşçi & Eskişehir \\
Büşra & Alt & 9 & Ev hanımı & İmam & Kütahya \\
Selin & Orta & 9 & Öğretmen & Öğretim üyesi & Afyon \\
Oğuzhan & Orta & 9 & Belediye başkan yrd. & Teknisyen & Eskişehir \\
Kenan & Orta & 8 & Doktor & Doktor & Bursa \\
Derin & Orta & 10 & Memur & Tekniker & Kütahya \\
Mehtap & Orta & 9 & Laborant & Laborant & Eskişehir \\
Ayşe & Orta & 11 & Öğretmen & Polis & Aydın \\
Selma & Orta & 11 & Tekniker & Tekniker & Aydın \\
Ceylin & Üst & 10 & Esnaf & Mühendis & Çorum \\
Adnan & Üst & 10 & Doktor & Banka Müdürü & Konya \\
Orkun & Üst & 9 & Mühendis & Mühendis & Ankara \\
Mehmet & Üst & 10 & Doktor & Doktor & Tekirdağ \\
Merve & Üst & 8 & Öğretmen & Öğretmen & Eskişehir \\
Suna & Üst & 10 & Hemşire & Doktor & İzmir \\
\hline Araştımayar
\end{tabular}

Araştırmaya katılan öğrencilerin orta ve yüksek sosyoekonomik düzeyde genellikle anne ve babaları çalışırken alt sosyoekonomik düzeydeki öğrencilerin anneleri genellikle ev hanımı olup babaları ise işçidir. Benzer şekilde orta ve üst sosyoekonomik düzeyde anne ve babaların eğitim durumu da alt sosyoekonomik düzeyden yüksektir.

Tablo 2. Öğretmenlerin Kişisel Özellikleri

\begin{tabular}{lccc}
\hline Kod isim & Hizmet yılı & Okulun SED & Mezun Olduğu Bölüm \\
\hline Ayla & 19 & Alt & Işletme \\
Tuğrul & 18 & Alt & Mühendislik \\
Mahmut & 16 & Alt & Sınıf Öğretmenliği \\
Emine & 26 & Üst & Sınıf Öğretmenliği \\
Hediye & 4 & Üst & Sınıf Öğretmenliği \\
Mustafa & 47 & Üst & Sınıf Öğretmenliği \\
Pervin & 31 & Orta & Sınıf Öğretmenliği \\
Zeynep & 23 & Orta & Sınıf Öğretmenliği \\
Fatih & 20 & Orta & Sınıf Öğretmenliği \\
İsmail & 35 & Orta & Sınıf Öğretmenliği \\
\hline
\end{tabular}

Araştırmaya katılan öğretmenlerin çoğu sınıf öğretmenliği mezunu iken sadece iki öğretmen işletme ve mühendislik mezunudur. Öğretmenlerin deneyimleri 4 ile 47 yıl arasında değişmektedir. Öğretmenlerin üçü alt sosyoekonomik düzey okulda, üçü üst sosyoekonomik düzeyde ve dördü orta sosyoekonomik düzeyde yer alan okullarda görev yapmaktadır.

\subsection{Veri Toplama Yöntemi}

Araştırmada ilkokullarda görev yapan dördüncü sınıf öğretmenleriyle ve onların öğrencileriyle yarıyapılandırılmış görüşme yapılmıştır. Görüşmeler ses kayıt cihazı kaydedilmiş ve okulda 
gerçekleştirilmiştir. Görüşmelerde öğrencilere ve öğretmenlere; “insan hakları, Yurttaşlık ve Demokrasi" dersine yönelik genel görüşleri, dersin içeriği, öğrencilerin öğrenmekten keyif aldığı ve zorlandığı konular, derslerde hangi etkinliklerin yapıldığı, derste öğrenci kazanımlarının değerlendirilmesi, yaşanan sorunlar ve çözüm önerileri sorulmuştur.

\subsection{Verilerin Analizi}

Verilerin analizinde tematik analizden yararlanılmıştır. Araştırmada sorulan sorular dikkate alınarak temalar oluşturulmuştur. Araştırmada verilerin kodlanması iki araştırmacı tarafından bağımsız yapılarak daha sonra karşılaştırılmış ve üçüncü araştırmacı tarafından yeniden değerlendirilmiştir. Dolayısıyla verilerin analizi sürecinde üç araştırmacının da bakış açısı karşılaştırılmıştır. Verileri öğretmen ve öğrenci görüşleri karşılaştırılarak analiz edilmiş ve bulgularda öğrenci ve öğretmenlerin görüşlerinden benzerlik ve farklılıkları belirtilmiştir. Bu benzerlik ve farklılıkların belirtilmesinde doğrudan alıntılardan yararlanılmış, alıntılar dikkate alınarak yorumlamalar yapılmıştır. Verilerin analiz edilmesinde MAXQDA nitel veri analizi programı kullanılmıştır.

\section{BULGULAR}

Araştırma sürecinde elde edilen bulgular elde edilen temalar bağlamında verilmiştir. Bu kapsamda dersin işlevi, içerik, öğrenme-öğretme süreci, değerlendirme, sorunlar ve öneriler temaları oluşturulmuştur.

\subsection{Dersin iş̧levi}

Öğretmen ve öğrencilerin tamamı dersin gerekli olduğunu düşünmektedir. Öğretmenler ve öğrenciler İnsan Hakları, Yurttaşlık ve Demokrasi dersini kendi bakış açıları ile değerlendirmiş, ortak ve farklı görüşler öne sürmüştür. (Şekil 1).

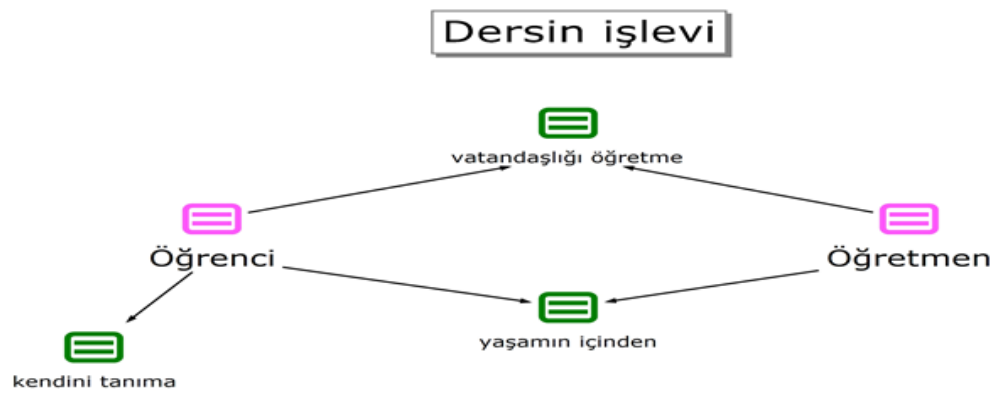

Şekil 1. Dersin işlevi

Şekilde görüldüğü gibi, öğretmenler ve öğrenciler ortak olarak insan Hakları, Yurttaşlık ve Demokrasi dersinin vatandaşlığı öğrettiğini ve dersin yaşamın içinden olduğunu dile getirmişlerdir. Bu dersin vatandaşlığı öğrettiğini söyleyen öğretmenler, insan hakları ve temel insani değerlerin öğrencilere kazandırılması konusunda dersi işlevsel olarak değerlendirmiştir. Örneğin, Pervin öğretmen dersin vatandaşlığa sağladığı katkıyı "Adaleti, saygıyı her şeyi bahsediyor insan haklarından" biçiminde açıklamıştır. Tuğrul öğretmen derste yer verilen öykülerde insan haklarının işlendiğini ve öğrencilerin bundan çok etkilendiğini dile getirmiştir. Tuğrul öğretmen görüşünü "Dersteki müfredat güzel. Yani oradaki öykülendirmeyle insan hakları konularına bakış açılarından acayip derecede öğrenciler ve ben etkilendik doğrusunu söyleyeyim" biçiminde dile getirmiştir.

$\mathrm{Bu}$ dersin yaşamın içinden olduğunu dile getiren öğretmenler dersin yaşamı öğrettiğini vurgulamışlardır. Örneğin, Mustafa öğretmen dersi yaşamın içinden görmesini "Bu dersin diğer derslerden farkı aslında bu ders tam hayata yaşama uygun bir ders onun için çok önem verilmesi gerekiyor" sözleriyle ele almıştır. Öğrencilerden bazıları da öğretmenler gibi bu derste yaşamı öğrenmeyi dile getirmişlerdir. Ceylin "Insan Hakları, Yurttaşlık ve Demokrasi" dersini haklarını öğrendiği için yaşamla iç içe olarak değerlendirmiştir. Ceylin bu dersi matematik dersi ile 
karşılaştırarak yaşamsallı̆ını şöyle açıklamıştır: "Mesela matematikte doğal sayıları öğreniyoruz kesirleri öğreniyoruz ama insan hakları yurttaşlık dersinde yaşamamızla ilgileniyoruz. Bu yüzden daha yararlı oluyor bizim için" biçiminde açıklayarak yaşamla bağdaştırmış ve bu yüzden işe yarar bulmuştur.

Bazı öğrenciler ise vatandaşlık ve yaşamı öğrenmenin dışında bu dersin kendilerini tanımalarına yardımcı olduğunu dile getirmiştir. Öğrenciler bu derste aktif oldukları ve günlük hayatlarında yaşadıkları olaylardan söz ettikleri için bu dersin kendilerini tanımalarına katkı sağladığını dile getirmiştir. Dersin kendini tanımasını sağladığı belirten Mehtap bu görüşünü "Önceden sahip olduğumuz şeyleri bilmemizi sağlaması. Yani kendi sahip olduklarımızı bize öğretmesi..." biçiminde açıklayarak dersin bireye kendi özelliklerini tanıtmada yardımcı olduğunu ele almıştır.

\subsection{Dersin İçeriği}

Öğrenciler ve öğretmenler dersin içeriğine ilişkin olarak öğrendikleri konular ile öğrenmekten keyif aldıkları ve zorlandıkları konular konusunda görüşlerini dile getirmiştir. (Şekil 2)

\section{İçerik}

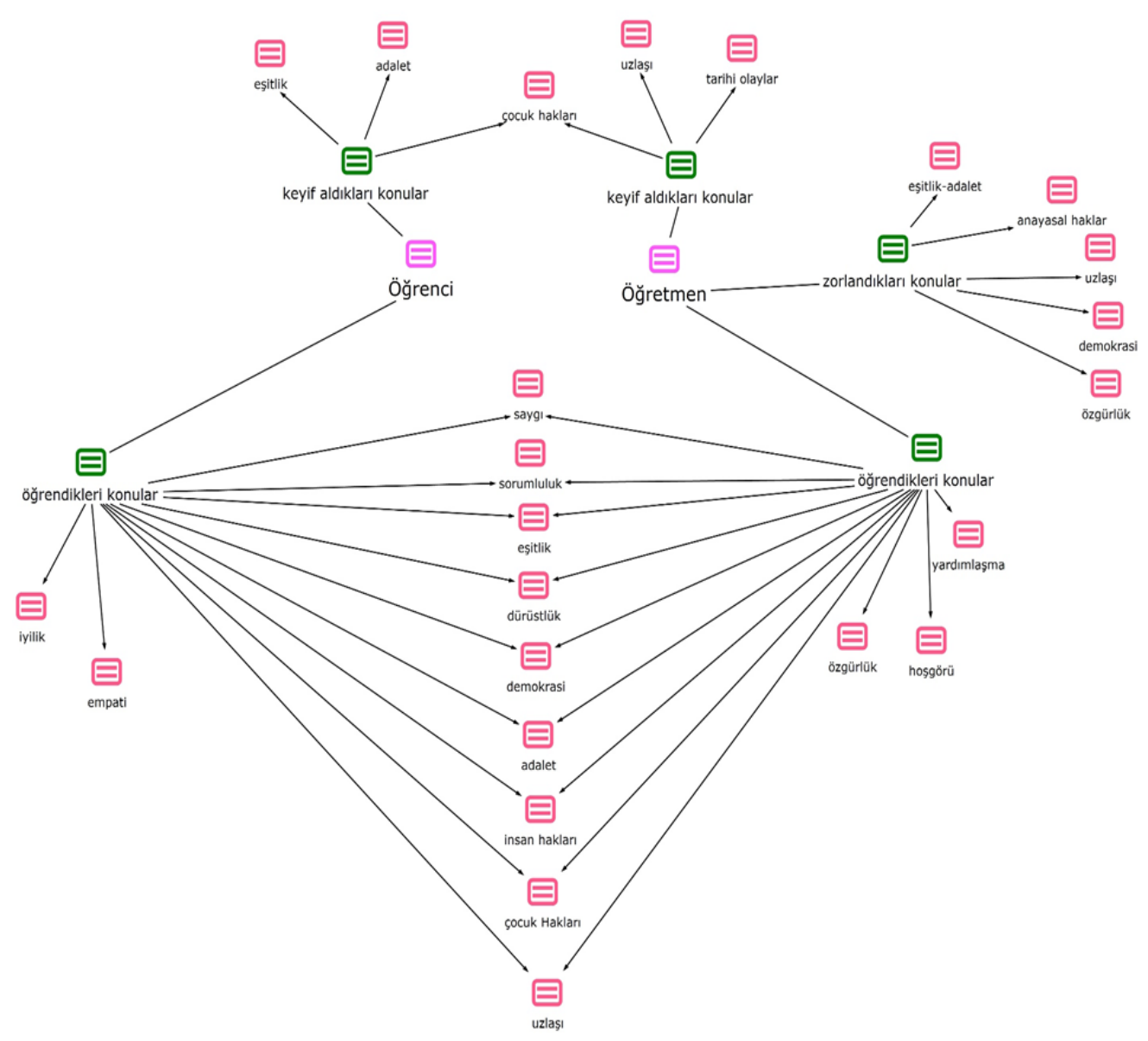

Şekil 2. Dersin içeriği 
Öğretmenler ve öğrencilerin görüşlerinden bu derste uzlaşı, saygı, sorumluluk, dürüstlük, eşitlik ve adalet gibi daha çok demokratik değerleri, demokrasi ve insan hakları bilgisi olarak sadece insan hakları ve çocuk haklarını öğrendikleri söylenebilir. Öğretmen ve öğrencilerin öğrenilen konularda ortak görüşleri, saygı, sorumluluk, eşitlik, dürüstlük, demokrasi, adalet, insan hakları, çocuk hakları ve uzlaşıda örtüşürken, öğrenciler iyilik ve empatiyi, öğretmenler ise özgürlük, hoşgörü ve yardımlaşmayı ayrıca dile getirmiştir. Örneğin, bu derste öğrendikleri konuları Derin “Bu ders bize insan haklarını anlatıyor. Biz daha bu dersi yeni görmeye başladık onun için bilmediğimiz şeyleri bu derste öğreniyoruz..." biçiminde dile getirmiştir. Tuğrul öğretmen ise bu derste öğrencilerinin insan haklarını nasıl öğrendiklerini farklı ortamlardan örnekler vererek şöyle ifade etmiştir:

Yurttaşlık tabiî ki şimdi sonuçta o kitaptaki hikâyelerde bir kendilerini korumayı kendilerinin hakkını öğreniyorlar iki ailelerin hakkını öğreniyorlar ailelerin neye hakları aile olarak ne gibi şeylere ihtiyaçları var üç bulundukları otağın eskiden örnek aldıkları için ya da mahallenin sokağın sokaktaki ilişkilerin hangi ilişkilerin nasıl olması gerektiğini öğreniyorlar dört yani en küçük aileden en büyük ülkesine milletine kadar nelere sahip olunması gerektiğinin nasıl sahip olunması gerektiğini hakikatin adaletin efendime söyleyeyim intiyaçların nasıl dağıtılabileceğini nasıl şey yapılabileceğini duyuyorlar yani alabildikleri kadar öğreniyorlar."

Öğretmen ve öğrenciler bu derste öğrenmekten hoşlanılan konular ve öğrenmekte zorlanılan konulara ilişkin görüş belirtmişlerdir. Öğretmen ve öğrenciler öğrenmekten hoşlanılan konulardan ortak olarak çocuk haklarına değinirken, öğrenciler eşitlik ve adalete, öğretmenler ise uzlaşı ve tarihi olaylara da değinmişlerdir. Öğrencilerin bu derste oyun hakkı, söz hakkı, okuma hakkı ve eğlence hakkı gibi haklarını öğrendikleri ve günlük hayatta bunlara yönelik farkındalıklarının arttığından dolayı keyif aldıkları ortaya çıkmıştır. Örneğin, Mehtap kendini ilgilendirdiği için haklarını öğrenmekten keyif aldığını "Çok iyi anladığım haklarımızı öğrenmek konusu, vatandaşlık görevlerimiz, sorumluluklarımız. Bizim için okula gitme, öğrenme, büyüklerimiz için askere gitmek, vergi verme gibi." ifadelerini kullanarak anlatmıştır. Hediye öğretmen ise "Kendilerinin sahip oldukları hakları bilmek onları mutlu ediyor. Mesela o kişi dokunulmazlığı ben istemeyince ailem bana dokunamaz falan öyle onlarda mutlu oldular." biçiminde açıklamıştır.

Öğretmenler bu derste öğrencilerin öğrenmekte zorlandıkları konuları eşitlik-adalet, anayasal haklar, uzlaşı, demokrasi ve özgürlük olarak belirtmişlerdir. Ayrıca eşitlik-adalet ve uzlaşının hem zorlanılan konularda hem de keyif alınan konularda yer aldığı ortaya çıkmıştır. Örneğin, Emine öğretmen eşitlik-adalet konusunda görüşlerini "Mesela en çok zorlanılan kavram adalet oldu. Mesela eşitlik ve adalet gibi kavramlar sanki adalet eşitlikmiş gibi algılamalar oluyordu. Hani bunların farklı kavramlar olduğunu vurgulamaya çalıştık. Bu kavramlar yabancıydı açıķası çocuklara." biçiminde açıklayarak kavram karmaşasına ve kavramların çocuklara uygun olmadığına değinmiştir. Öğretmen görüşlerine göre öğrencilerin öğrenmekte zorlandıkları anayasal haklar, uzlaşı, demokrasi ve özgürlük gibi konular incelendiğinde bu konuların tamamının soyut kavramlardan oluştuğu ve araştırmanın yapıldığı yaş dönemi incelendiğinde somut işlem döneminde olan öğrencilerin bu kavramları içselleştirmede zorluklar yaşamasının doğal olduğu söylenebilir.

\section{3 Öğrenme-Öğretme Süreci}

Insan hakları, Yurttaşlık ve Demokrasi Dersi Öğretim Programı́nda öğretim sürecinin öyküler ile işlenmesinin önerilmesi nedeniyle öğretmenlerin çoğunlukla dersi öyküler yoluyla işledikleri, bazı öğretmenlerin de öyküler dışında farklı öğretim yöntem ve tekniklerine yer verdikleri görülmüştür. (Şekil 3) 


\section{Dersin işlenişi}

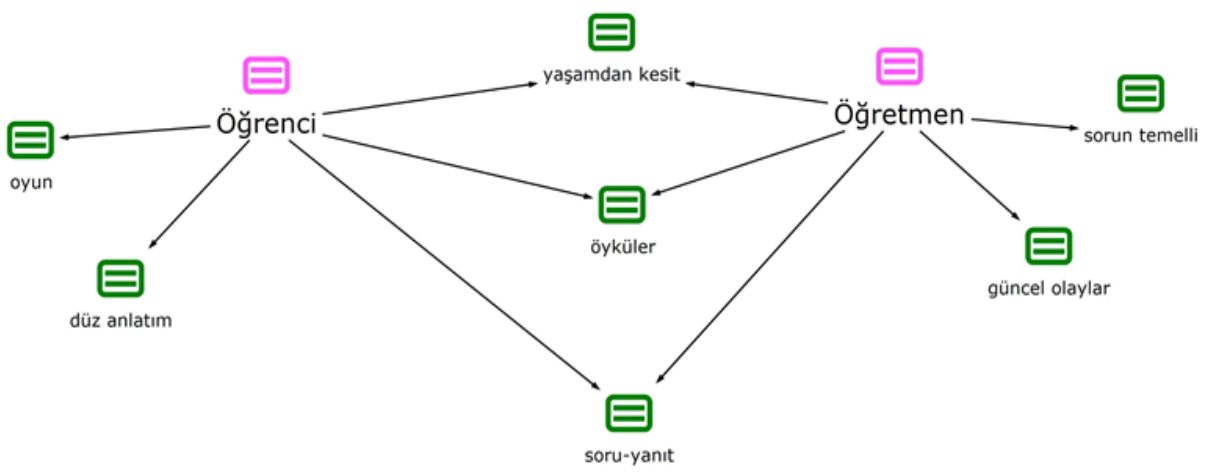

Şekil 3. Öğrenme-Öğretme Süreci

Insan Hakları ve Yurttaşlık dersinin işlenişine ilişkin olarak öğrenciler ve öğretmenler ortak olarak yaşamdan kesit sunma, öykülerle işleme ve soru-yanıtı dile getirirlerken, öğrenciler oyun ve düz anlatımı da ele almıs, öğretmenler ise sorun temelli yaklaşım ve güncel olayları eklemiştir. Öğretmenler dersin işlenişinde öğrencilerin daha etkin olduğu ve yaşama dönük örneklerin yer aldığı uygulamalara yer verdiklerini ve böylece etkili ve kalıcı öğrenmelerin gerçekleşeceğini düşündüklerini ifade etmişlerdir. Örneğin, Ceylin dersi öykülerle nasıl işlediklerini "Sınıfta bu dersi öğretmenimiz bir parça vardı mesela okutuyor o okuttuğu parçayı sonra bize soruyor ne öğrendiniz buradan sonra duygu düşünceler adlı yeri okuyor orada ki yazıları bizim cevaplamamızı istiyor." biçiminde açıklamıştır. Tuğrul öğretmen süreci güncel olaylarla desteklediğini ifade ederek görüşlerini "Bizim yaşantımızda başımıza neler geliyor bununla ilgili bir şeyler gördük mü yaşadık mı haberlerde böyle bir şey duydunuz mu etrafınızda akrabalarınızda örnek olacak böyle adaylar var mı onları konuşuyoruz. Dolayısıyla ilişkilendirmiş oluyoruz yaşantımızla." biçiminde açıklamış ve güncel olayların yaşamla ilişkilendirmeyi sağladığını ifade etmiştir. Pervin öğretmen dersin işlenişinde öğrencilerin yaşamlarından kesitlere yer verdiğini 'Haksızlığa uğradıysa çevresinden de örnek veriyor hani terapi olabiliyor orada. Daha etkili oluyor' sözleriyle ifade etmiştir. Ayrıca Pervin öğretmen derste öyküden nasıl yararlandığını şöyle açıklamışıı:

Öyküleştirerek ulaşmaya çalışıyorum çocuğa. Çünkü onu hak nedir deyip bıraksam onun cümlesini bile kuramayacak belki işte biz bunu o derste öyküleştiriyoruz öyküleştirdikten sonra anladıklarını özetletiyorum. Hani hangi bölümler akıllarında kalmış çünkü onu yaşama geçirmesi belki daha kolay olur diye düşünüyorum. Kısa yazdıkları bölümleri inceliyorum. Hani mesela biz çirkin ördek yavrusunu işledik çocuklarla anlattım onlara. Daha sonra orada işte sevilmemesi olduğundan dolayı şeklinde hani bunun sonrasında çocuklarla hani bunu tartışabildik.

Öğrenciler derste kullanılan öykülerin özelliklerine öğretmenler ise öyküleri nasıl seçtiklerine ilişkin görüş belirtmiş̧lerdir. (Şekil 4) 


\section{Öyküler-Öykü Seçimi}
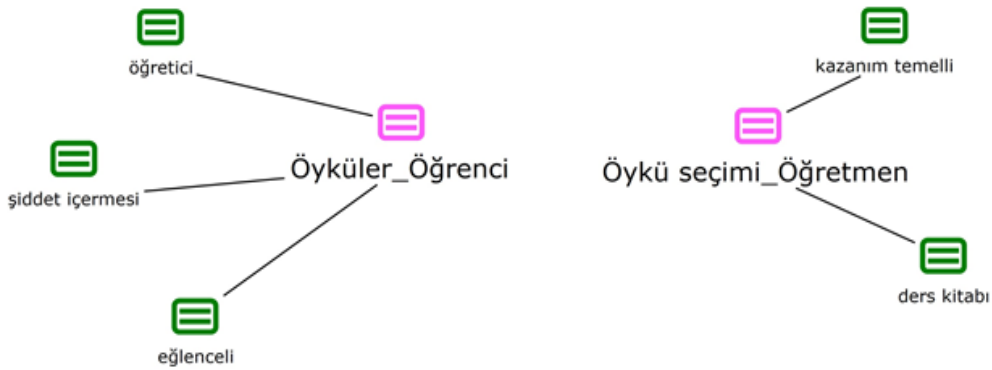

Şekil 4. Öyküler-öykü seçimi

Öğrenciler öyküleri öğretici ve eğlenceli bulurken bazı öğrenciler de şiddet içerdiğini ifade etmişlerdir. Öykülerden bazılarının şiddet içerdiğini ifade eden Suna bu görüşünü "Yani masallar güzel ama yani bazıları biraz şiddet içeriyor. Mesela bir tane metin vardı. Yeni bitirmiştik. Neydi adı? adını tam hatırlamıyorum. Böyle işte bir tane han vardı ha Ermankan han daha sonra onun bir tane oğlu oluyor Kudaynazar isimli böyle o kudaynazar çok böyle şiddete başvuruyor. Böyle her yeri yakıp yıkıyor. Kimse ona bir şey yapmamasına karşı böyle Ermankan handa böyle bir tane köy veriyor." biçiminde açıklayarak öyküden örnek vermiştir. Ancak Suna bu görüşünün yanı sıra öykülerin öğretici olduğunu da ekleyerek görüşlerini "Kitaptaki masalları okuyoruz bence güzel masallar yani gayet öğretiyor insan haklarıyla ilgili bayağı bir şeyi." biçiminde açıklamıştır. Orhan öykülere ilişkin olarak "Hem eğlenceliler hem de çok bilinçlendirici eğitici öyküler." görüşlerini ifade ederek hem eğlenceli hem de öğretici bulduğunu söylemiştir.

Öğretmenler öykü seçiminde kazanımları göz önüne aldıklarını ve hemen hemen hepsi ders kitabındaki öyküleri kullandıklarını söylemişlerdir. Ancak yalnızca bir öğretmen öykü seçiminde kazanıma uygun başka öykü kitaplarından da yararlandığını ifade etmiştir. Örneğin, Mahmut öğretmen "Ders kitabında ne varsa onu şey yapmaya başladık. O kitabın sonundaki soruları da öğrencilere soruyoruz. Orada düşünelim tartışalım var. Orada vermek istediğimiz mesajı orada veriyoruz yani. Ama şeyde çok kopuyor çocuk biz ne yaptık şimdi ne işledik falan oluyor yani dersin sonunda." biçiminde ders kitabındaki öyküleri kullandığını belirtmiştir. Kazanımları göz önünde bulundurduğunu ifade eden Ayla öğretmen ise kitaptaki kazanımlara göre öykü seçtiğini “Konuyla ilgili bağlantılı olmasına dikkat ediyorum. Önce parçayı bir okuyorum ben öncede zaten diyorum burada ne vermesi gerekiyor şu şu şu ona göre bir şeyler bulmaya çalışıyorum yani...Genelde kitaba bağlı kalmaya çalışıyorum yani. Kitapta verilmek istenen kazanıma göre çocuğa bir şeyler vermeye çalışıyoruz." biçiminde ifade etmiştir.

\subsection{Değerlendirme}

Insan hakları, yurttaşlık ve demokrasi dersinin değerlendirilmesinde öğrenciler ve öğretmenler ortak olarak davranışa yansıtma ve yazılı sınavı ele alırken, öğrenciler paylaşımı, öğretmenler ise sözel ifadeler ve ev ödevini belirtmişlerdir. (Şekil 5). Öğrencilerin ve öğretmenlerin yazılı sınavlar dışında öğrendiklerini davranışa dönüştürmeyi ifade etmesi sadece geleneksel değerlendirmeyi düşünmediklerini göstermektedir. 


\section{Değerlendirme}

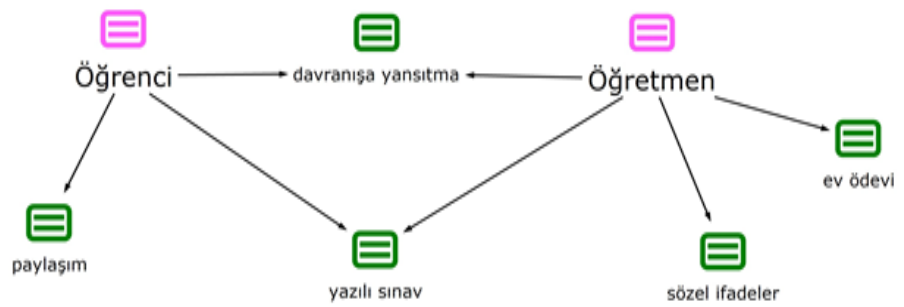

Şekil 5. Değerlendirme

Bazı öğrenciler derste işledikleri konuları yazılı sınav olduklarında değerlendirebildikleri açıklarken bazı öğrenciler derste işledikleri konuları davranışlarına uyguladığında öğrendiğini düşünmekte, bazıları ise çevrelerindeki kişilerle paylaştıklarında öğrendiklerini düşünmektedir. Örneğin, Adnan "O davranışları uygulayarak yeni şeyler öğrendiğimi anlıyorum." biçiminde belirterek öz değerlendirmeyi vurgulamıştır. Selin ise bunu "Mesela bu derslerde anladığım hikâyeleri aileme anlatarak daha iyi kapsamış daha iyi kavramış oluyorum. Ne anladığımı dediğim gibi daha çok deneyerek anlıyorum. Arkadaşlarımla konuşarak anlıyorum. Onların ailesinden duyduklarımla kıyaslayarak anlayabiliyorum. Kendi ailemi ve çevremi kıyaslayarak anlayabiliyorum..." görüşleriyle açıklayarak bilgi paylaşımını bir değerlendirme türü olarak ifade etmiştir.

Öğretmenler ise öğrencilerin bu derse ilişkin kazanımlarını yazılı sınav, davranışa yansıtma, sözel ifadeler ve ev ödevi biçimiyle değerlendirdiğini söylemiştir. Ancak, öğretmenlerin söylemlerinden öğrencilerin davranışlarını değerlendirirken yalnızca gözlem yaptıkları ve herhangi bir değerlendirme aracı geliştirmedikleri görülmektedir. Örneğin, Ayla öğretmen "Zaten çocuğu tanıyorsunuz dört yıldır birliktesiniz çocuğu. Verdikleri cevaplara göre değerlendiriyorum. Veya uyguladıkları davranışlara göre değerlendiriyorum." ifadelerini kullanarak öğrencilerin davranışlarını vurgulamıştır. Paylaşımı bir öz değerlendirme olarak ele alan Tuğrul öğretmen öğrencilerin sözel ifadelerini kullandığını “Dersin değerlendirilmesinde... ilişkili sorular söylüyoruz yani o masallarla falan ilgili günlük hayatta karşılaştığımız çocukların ailelerinin ülkemizin başında olan ilişkilendirilmiş sorular soruyoruz. Çocuklarda da başarının iyi olduğunu gördüm yani geçtiğimiz dönemde" görüşleriyle açıklamıştır.

\subsection{Yaşanan Sorunlar}

Öğrenciler ve öğretmenler bu derste yaşanan sorunlarda ortak olarak bilinmeyen kelimeler ve uygulama eksikliğini ele alırken, öğretmenler olumsuz aile tutumu, soyut konular, içeriğin yoğunluğu ve seviye üstü olması, öğretmenin bilgisinin az olması ve kitabın ulaşmamasını da eklemişlerdir. (Şekil 6) 


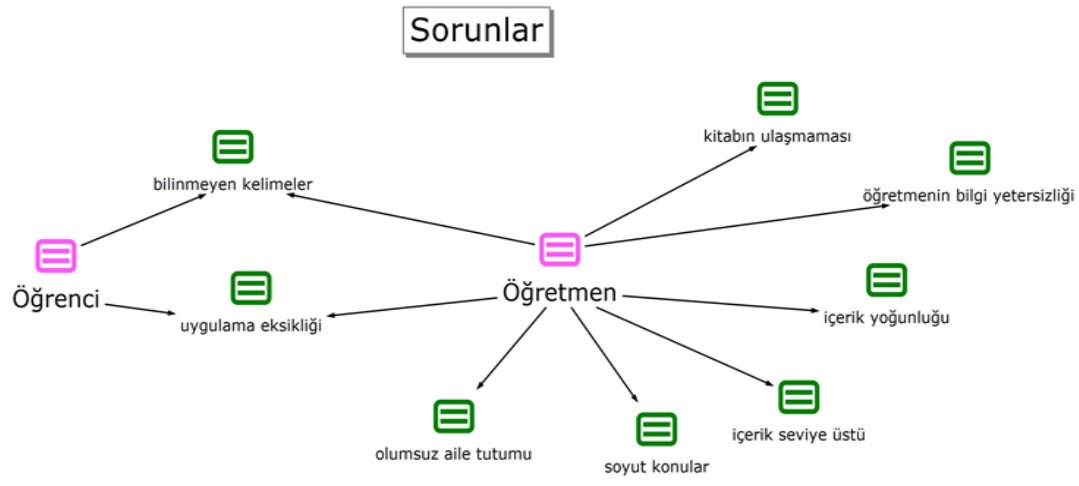

Şekil 6. Yaşanan sorunlar

Öğrencilerin derse ilişkin sorunlar üzerinde en çok dile getirdiği bilinmeyen kelimeler olmuştur. Öğrenciler daha çok öykülerde bilmedikleri kelimeler çok olduğunu ve bu nedenle anlamakta zorlandıklarını dile getirmişlerdir. Örneğin, Berna görüşünü "Anlamadığım sözcükler çıkıyor." biçiminde ele alırken, Orkun "Bazı kelimeleri anlamıyordum." biçiminde ele almıştır. Bu konuda öğretmenler çocukların günlük yaşamında karşılaşmadığı kelimelerin öykülerde çok yer aldığını ve ağır bir dil kullanıldığı için çocukların anlamakta zorlandıklarını dile getirmiştir. Fatih öğretmen bu sorunu "...bir ara baktım ben şeydi sırf masal üzerinden işlenmiş. Çok garip isimler vardı balıkçının oğlunun başından geçenler mi yani kelimeler de tuhaftı yani çocukların algılama. Biraz şeye dönüşmüş Osmanlı ya da islamiyet güzellemesi kelimeleri direk şeylerden anlıyorsun zaten konu başlıklarından." biçiminde ifade etmiştir. Öğrencilerden bazıları öğrendiklerini uygulamadıklarını dile getirmişlerdir. Uygulama eksikliğine ilişkin olarak öğrencilerden Adnan sorunu "yani öğreniyorlar ama bir süre sonra davranışı yapmayı unutuyorlar." biçiminde ifade etmiştir. Öğretmenlerden bazıları da benzer şekilde uygulama eksikliğinden söz etmiştir. Örneğin, Mustafa öğretmen "şu biz bir dersi koyduk. Bu dersi koymakla biz çocuklarımıza insanlarımıza insan hakların öğrettik yurttaşlık ve demokrasiyi öğrettik diye yüzeysel olmamalı gerçekten öğretilmeli. Gerçekten uygulanmalı. Sanki dersi koyduk deyince her şey hallolmuş gibi diye düşünülüyor. Ama dersi koymakla iş bitmiyor önemli olan uygulamak onu sonuçlandırmak ona gerçekten zaman ayırmak." biçiminde ele alarak yalnızca dersin yeterli olmadığını ifade etmiştir. Öğretmenlerin dile getirdiği bir başka sorun ders kitabı ile ilgilidir. Öğretmenler ders kitabının geç gelmesinin zaman kaybına neden olduğunu ifade etmiş ve Hediye öğretmen bu durumu "Çünkü kitap geç geldiği için kitap olsa biz hani programı önceden yapacaktık ama kitabın geç gelmesi biz ne yapacağımızı hani yani çok zaman kaybettirdi bize." biçiminde açıklamıştır. Mustafa öğretmen ise, içerik yoğunluğunu bir sorun olarak ele almış ve görüşlerini "Konuların çok fazla olması onların üzerinde daha bir sadeleștirme yapılmalı diğer derslerimizde de var bizim. Konuların çok fazla olması..." biçiminde açıklamıştır. Bazı öğretmenler olumsuz aile tutumlarını sorun olarak ele almışlardır. Örneğin, Ayla öğretmen "Yani biz burada çocukları ne kadar yönlendirirsek yönlendirelim evlerde ailede uygulama farkı olduğu için bir çatışma ortaya çıkıyor. Biz burada a diyorsak aile orada tam tersi b'yi uyguluyor çocuk ikilemde kalıyor. Uygulamada zorluk çekiyor. çoğu zaman aileyle birlikte olduğu için günlük aileyle yaşantısını daha fazla geçirdiği için biz burada çok zorlanıyoruz..." biçiminde açıklayarak okul ile aile arasında yaşanan çelişkiyi ifade etmiştir.

\section{6 Çözüm önerileri}

Öğrenciler ve öğretmenler ortak olarak dersin etkili olmasına ilişkin görsel materyaller kullanmayı ve günlük yaşamla ilişkilendirmeyi önermişlerdir. Bu konuda öğrenciler ders saatinin artııılması, kaynak kitaplardan, öykülerden ve oyunlardan yararlanılması ve canlandırmalar yapılmasını önerirken, öğretmenler uygulamaya önem verilmesini, fırsat eğitiminden ve grup çalışmalarından yararlanılmasını, kitapların yeniden düzenlenmesini, diğer derslerle ilişkilendirmeyi, daha alt 
sınıflarda yer almasını, konuların sadeleştirilmesini, ailenin destek vermesini ve rol model olunması gerektiğini önermişlerdir. (Şekil 7).

\section{Öneriler}

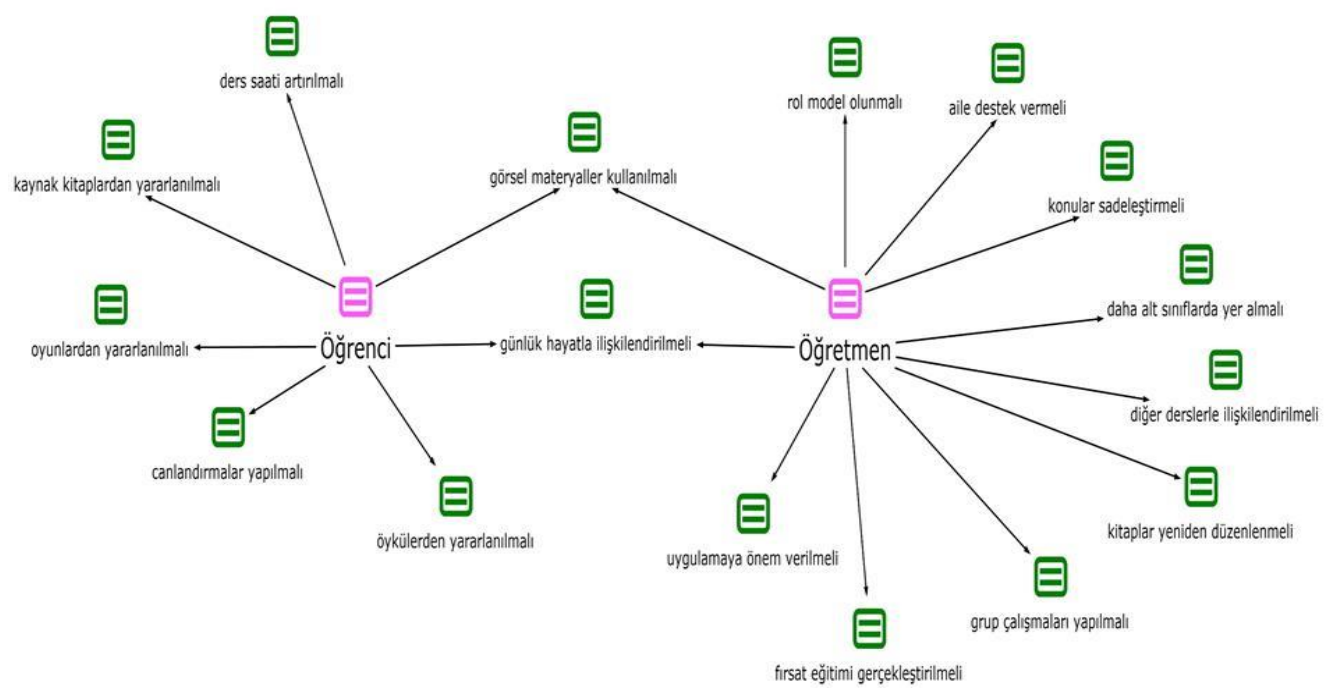

Şekil 7. Öneriler

Insan Hakları, Yurttaşlık ve Demokrasi dersinde görsel materyaller kullanılması öğretmenlerin ve öğrencilerin en çok dile getirdikleri öneriler arasında yer almaktadır. Öğrenciler ve öğretmenler video, film izleme, resim yapma gibi çeşitli görselleştirme araçlarını derste kullanmayı önermişlerdir. Örneğin Adnan görüşünü "Panoya yapılan davranışları resim yaptırıp asabilirim." biçiminde ifade ederken, Suna "CD'ler hazırlardım... Öğrencilere izlettirirdim" biçiminde ifade etmiştir. Mustafa öğretmen ise bu konuyu "Başka şimdi şöyle bu konularla ilgili önceden düzenlenmiş filmler olabilir tiyatro olabilir daha sonra çocukların kendilerinden bu konularla ilgili deneme yapmaları istenebilir." ifadeleriyle ele alırken, İsmail öğretmen "Mesela bakın resimli kitap olabilir bak resimli çocuklar resimden daha hoşlanır." biçiminde ele almıştır. Dersin işlenişin görsel- işitsel materyallerin kullanılmasına yönelik önerilerde bulunulması öğrencilerin yaş dönemi ile ilişkili olabilir. Günlük hayatla ilişkilendirmeyi önemli gören öğrencilerden Ceylin bu görüşünü “Ben öğretmen olsam mesela bugün ders sonunda ne iyilik yaptın yaptığımız iyilikleri arkadaşlarınla nasıl bir şekilde bulundun onları sorardım herkese sırayla sonra da devam ederdim." biçiminde ifade ederek arkadaşlarıyla öğrendiklerini paylaşmayı ele almıştır. Emine öğretmen ise bu konudaki görüşünü "Çocuk kitabı yazarlarımız bunlara uygun belki bu kavramalara uygun günlük yaşamla da bağdaştıracağımız şekilde daha uygun daha güncel masallar yazılabilir. Hani bizim çok zamanımız yok belki bunu biz de yapmak isteriz ama çok zamanımız yok bu şekilde çalışmaya ama hani bu konuda uzman olan kişiler çocuk psikolojisinden anlayan yazanlar bu şekilde bu masalları da yazabilirler. Çünkü kitabımızdaki masallar gerçekten uzak yani günlük hayat" biçiminde ele alarak masalların yaşamın içinden olmasına vurgu yapmıştır. Ders saatinin artırılması gerektiğini düşünen öğrencilerden Suna görüşünü “Bence gayet güzel bir ders. Haftada iki saat bize çok yetmiyor gerçekten çok önemli bir ders. Bence gayet güzel bir ders yani sevdik sevdiğim bir derslerden birisi." biçiminde açılayarak derse olan olumlu tutumunu ifade etmiştir. Derslerde oyunlardan yararlanılması gerektiğini düşünen Derin ise bu görüşünü "Derste geçen konuları sessiz sinema oyununa uyarlardım. Daha eğlenceli hale getirirdim." biçiminde açıklayarak dersin daha eğlenceli hale geleceğinden söz etmiştir. Öyküleri canlandırmanın etkili olacağını düşünen Orhan görüşünü “Derste geçen konuları Sessiz sinema oyununa uyarlardım. Daha 
eğlenceli hale getirirdim." biçiminde açıklamıştır. Konuların sadeleştirilmesi gerektiğini düşünen Ayla öğretmen görüşlerini "Çözüm önerilerim dediğim gibi o kitabın özellikle çocukların seviyesine göre basılması tekrar gözden geçirilmesi gerekli. Çok çok insan hakları bu tamam çocukların çok iyi verilmek istenen çok iyi şeyler var ama seviyenin üstünde dördüncü sınıf seviyesinin çok çok üstünde diye düşünüyorum." biçiminde ifade ederek içeriğin çocuklara göre düzenlenmesi gerektiğini ele almıştır. Ayla öğretmenin görüşlerinden ders için hazırlanan kitabın çocukların seviyesinin oldukça üstünde olduğu anlaşılmaktadır. Benzer görüşü savunan Mustafa öğretmen de hem konuların sadeleştirilmesi gerektiğini hem de ailenin destek vermesi gerektiğini ifade ederek görüşlerini "Konuların azaltılması konular azaltıldıktan sonra bu süre içinde sadece okuma anlatma yorumlama şeklinde değil de her böyle bölümle ilgili sınıfın katılabileceği böyle gösteriler olabilir. Bu gösterilere velileri de davet edelim. Onlar da izledikleri zaman onlar da bundan bir sonuç çıkarır. Ve dersi daha geniş kitleye yaymış oluruz." biçiminde açıklamıştır. Diğer derslerle ilişkilendirmeyi önemseyen Zeynep öğretmen ise görüşünü "Bütün derslerde dağıtılarak da sürekli hatırlanması gerektiğini düşünüyorum." biçiminde açıklamıştır. Buna göre öğretmenlerin ve öğrencilerin öneri olarak çok farklı boyutlara değindikleri hem sınıf içi süreçleri hem sınıf dışı etkinlikleri hem de dersin içeriğini ele aldıkları söylenebilir.

\section{SONUÇ, TARTIŞMA ve ÖNERILER}

Araştırma sonucunda, Insan Hakları, Yurttaşlık ve Demokrasi dersine ilişkin öğretmen ve öğrencilerin büyük ölçüde benzer görüşler öne sürdürdükleri görülmektedir. Öğretmen öğrencilerin demokrasi ve insan haklarına ilişkin tutumlarının olumlu yönde değiştiğini söyleyerek dersi işlevsel bulduklarını belirtmişlerdir. Öğrencilerin de demokrasi ve vatandaşlığa ilişkin temel bilgi ve değerleri edindiğini söylemesi dersin işlevsel oluğunu göstermektedir. Bu sonuç, Kaymakçı ve arkadaşları (2015) tarafından yapılan araştırma sonuçları ile desteklenmektedir. Ancak, öğretmenler öğrencilerin demokratik değer ve tutumlarında bir gelişme olmasından söz ederken öğrencilerin düşünme ve katılım becerilerine yönelik bir gelişmeden söz etmemişlerdir. Bu durum Insan Hakları, Yurttaşlık ve Demokrasi dersinin içeriğinden ve dersin işleniş biçiminden kaynaklanabilir. Insan Hakları, Yurttaşlık ve Demokrasi dersi öğretim programı daha çok uzlaşı, saygı, hoşgörü, eşitlik gibi demokratik değerler üzerine yapılandırılmıştır. Oysa vatandaşlık ve demokrasi eğitimi yalnızca demokratik tutum ve davranışların eğitimi üzerine odaklandı̆̆ında eksik kalabilir. Araştırma sonuçları yeterli vatandaşlık bilgisine sahip olmayan bireylerin vatandaşlık katılımının da yeterli olmadığını, demokrasinin sürdürülebilmesi için gerekli etkin vatandaşlık yeterliklerine sahip olunmasını gerektiğini göstermektedir (Torney-Purta et al, 2001; Göz, 2010). Vatandaşlık eğitiminde siyasal okuryazarlık, toplumsal katılım, sosyal ve ahlaki sorumluluk birlikte geliştirilmelidir. Bu amaçla, derslerde öğrencilerin düzeyine uygun siyasal ve sosyal olayları tartışmasına, bu olaylara çözüm üretmeye çalışmasına ve toplumda etkin rol almasına yönelik etkinlikler yapılmalıdır. Bu dersin etkili vatandaşlık eğitimi kapsamında yeniden düzenlenerek devam etmesi ve her sınıf düzeyinde süreklilik gösterecek biçimde ayrı bir ders olarak yapılandırması öğrencilerin vatandaşlık gelişimi açısından gerekli olacaktır. Ayrıca, bu dersin öğretim programında öğrencilerin demokrasi değerlerini daha çok ulusal ve tarihi öyküler yoluyla öğrenmesi temel alınmış ve ders kitaplarında bu öykülere yer verilmiştir. Ancak, demokratik değerlerin evrensel insan hakları değerleri olduğu düşünülerek farklı ülkelerden de örnekler sunulması öğrencilerin küresel bakış açısının gelişmesinde yararlı olacaktır. Çünkü günümüzde dünya vatandaşlarının yetiştirilmesi birçok ülkenin eğitim amaçları arasında yerini almıştır (Balbağ, 2016).

Bu derste öğretmenler genellikle ders kitabındaki öykü ile ders işlemişlerdir. Öğretmenler Türkçe dersinde olduğu gibi öyküleri okuma, bilinmeyen kelimelerin bulunması ve sorular ile öykü çözümlemesi yapmışlardır. Öğretmenler öyküleri, çok uzun, soyut, öğrenci düzeyinin üstünde ve anlaşılmayan kelimelerin çok olması nedeniyle eleştirirken öğrenciler öykülerden hoşlandıklarını söylemişlerdir. Öğrencilerin öykülerden hoşlanması, geleneksel öğretmen merkezli öğretimden 
farklı bir yöntemle dersin işlenmesine bağlanabilir. Çünkü öğrenciler öykülerle ders işlemekten memnun kalmışlardır. Ancak, bazı öğrenciler eleştirel bir bakışla bazı öykülerin şiddet içerdiğini ve anlaşılmasının zor olduğunu dile getirmiştir. Bu nedenle, bu derste yer verilen öykülerin daha güncel içerikli, dil ve anlatım açısından daha anlaşılır olması öğrencilerin soyut olan demokratik değerleri somutlaştırabilmesine ve anlamasına olanak sağlayacaktır. Piaget'in bilişsel gelişim kuramına göre, dördüncü sınıfta öğrenciler dokuz yaşlarında ve somut gelişim döneminde olmaktadır. Bu nedenle, soyut kavramların somutlaştırılarak öğretilmesi amacıyla yaşamla ilişkilendirme, benzetmeler yapma, görselleştirme gibi etkinlikler yapılabilir. Ayrıca, öğrencilerin bu derste yer verilen demokratik değerleri özümsemesi için kendisinde var olan bilişsel yapı ile uyum göstermesi ve ilişkilendirebilmesi gerekir. Çünkü günümüz eğitim anlayışında yaşam becerileri ve değerler öğrencilere kazandırılması planlanan en önemli özelliklerdir (MEB, 2005; Katılmış, Ekşi \& Öztürk, 2010; Kamber, Acun \& Akar, 2011; Acun ve diğerleri, 2013; MEB, 2015; Akar, 2016). Bireyin karşılaştığı yeni bir olay, durum, bir fikir, kendisinde daha önce var olan bilişsel yapı içerisine alabilirse özümseme gerçekleşebilir (Senemoğlu, 2007). Bu nedenle, bu derste öğrenilen kavramların öğrencilerin daha önceki bilişsel yapıları ile ilişkilendirilmesi sağlanmalı, derslerin bu açıdan birbirini destekler düzeyde olması sağlanmalıdır. Ayrıca, ders kitabındaki öykülerin bu açıdan yeniden gözden geçirilmesi ve bu ölçütlere uygun öykülerin öğretim materyali olarak kullanılmaması ve yeniden düzenlenmesi sağlanabilir.

Öğrenme ve öğretme sürecinde öğretmenlerin bu dersi Türkçe dersi gibi işlediği ve öğrencilerin de dersi Türkçe dersi gibi algıladığı ortaya çıkmıştır. Öğretmenler, derste öyküleri okuduktan sonra bilinmeyen kelimeleri çıkarıp parçaya ilişkin soruları çözdüklerini dile getirmiştir. Yalnızca birkaç öğretmen derste farklı yöntemler uyguladığını söylemiştir. Bu derste öğrenme ve öğretim sürecinde yalnızca öykülere dayalı bir öğretim yaklaşımının benimsenmesi etkin öğretim ve öğrenci merkezli eğitim açısından yeterli olmayabilir. Bu derste öykülerle öğretimin yanı sıra örnek olay anlatımları, drama, problem çözme, işbirliğine dayalı öğretim, proje yapma gibi vatandaşlık eğitiminde kullanılabilecek birçok yöntem işe koşulabilir (Ersoy, 2007). Ayrıca, öğrenci ve öğretmenin de vurguladı̆̆ı gibi uygulamaya yönelik bir eğitim verilmesi gerekliliği, öğrencilerin edindiği bilgi ve değerlerin içselleştirilmesi ve kalıcı olması açısından önem taşımaktadır.

Araştırma sonucunda öğretmenlerin öğrenci kazanımlarını geleneksel değerlendirme teknikleri ile değerlendirdiği görülmektedir. Bazı öğretmenlerin öğrenci davranışlarını gözlemlediklerini ifade etmelerine karşın bunu bir değerlendirme aracı ile gerçekleştirmedikleri ortaya çıkmaktadır. Ancak, derste öğrencilere verilen demokratik değer ve tutumların değerlendirilmesinde geleneksel değerlendirme tekniklerinin kullanılması sınırlı olacaktır. Bunun yanı sıra, değer ve tutumların değerlendirilmesinde yararlanılan alternatif değerlendirme tekniklerinin işe koşulması öğrenci kazanımlarının değerlendirilmesi açısından daha etkili olacaktır. Çünkü geleneksel değerlendirme tekniklerinin işe koşulması öğrencilerin demokrasi ve vatandaşlık değerlerinin ne derece kazanıldı̆̆ını belirlemede yetersiz kalabilir. Ayrıca, öğretmenlerin bu dersi öğrenci düzeyine göre işleme konusunda sorun yaşadığını ve öğrencilerin birçok konuyu anlamada zorlandıklarını söylemeleri öğretmenlerin mesleki yeterliği konusunu gündeme taşımaktadır. Öğretmenlerin İnsan Hakları Yurttaşlık ve Demokrasi dersinde kendilerini yeterli bulmamakta ve bu konuda eğitim gereksinim duyduklarını söylemektedir. Araştırmanın bu sonucu, vatandaşlıkla ilgili birçok araştırma sonuçları ile örtüşmektedir. Vatandaşlık eğitimine ilişkin alanyazında yer alan araştırmalarda da öğretmenler bu konudaki eğitim gereksinimlerini dile getirmişlerdir (Basaran, 2007; Balbağ ve Gürdoğan Bayır, 2016; Ersoy, 2007; Ersoy, 2014; Ersoy, 2016; Güven ve Şahin, 2010; Ülger, 2012). Öğretmenlerin bu konuda eğitim gereksinimlerini gidermek için hizmet öncesinde öğretmen eğitim programlarında zorunlu olarak vatandaşlık eğitimi dersleri konulması öğretmenlerin vatandaşlık eğitimi konusundaki yeterliğinin artırılması açısından önem taşımaktadır. Öğretmenlerin hizmet içi eğitiminde seminerler ile bilgilendirilmesi öğretmenlerin bu konudaki yeterliklerine katkı sağlayacaktır. 
Sonuç olarak, İnsan Hakları, Yurttaşlık ve Demokrasi dersi geliştirilerek diğer sınıflarda da devam ettirilmelidir. Bu araştırma sonucunda ortaya çıkan eğitim ve uygulama eksikliği, öğretmen yetersizliği, geleneksel öğretim ve değerlendirme yaklaşımlarının kullanılması, içeriğin yetersizliği, ders kitabı ve materyallerin eksikliği gibi sorunların vatandaşlıkla ilgili daha önce yapılan araştırma sonuçlarıyla örtüşmesi vatandaşlık eğitimi derslerinin programda yer ve ad değiştirmesiyle birlikte niteliğin ve işlevselliğin değişmediğini göstermektedir. Bu durum vatandaşlık dersinin yerinin programdaki yeri kadar nasıl verildiğinin önemli olduğunu ortaya koymaktadır.

Araştırma sonuçları göz önünde bulundurulduğunda şu öneriler getirilebilir:

- Araştırmada öğretmen ve öğrencilerin konuların günlük yaşamla ilişkilendirilmesi gerektiği sonucuna ulaşılmıştır. Bu nedenle, ders işlenirken uygulamaya yönelik, yaşamın içinden etkinliklere yer verilmelidir.

- Araştırma sonucunda öğrencilerin farklı yöntem ve tekniklerle dersin işlenmesinin daha etkili olacağı sonucu ortaya çıkmıştır. Bu nedenle, öğretmenler derste farklı kaynakları kullanarak öğrencileri etkin hale getirecek yöntem ve tekniklerden yararlanmalıdır. Ayrıca, öğretmenlere derslerde kullanabileceği, görsel ve işitsel öğretim materyalleri geliştirilmelidir.

- Öğretme-öğrenme sürecinde öykülerle ilgili öğrencilerin ve öğretmenlerin bir takım sorunlar yaşadığı ortaya çıkmıştır. Bu nedenle, öğretim programında öngörüler öyküler yaşanan sorunlar dikkate alınarak gözden geçirilmelidir.

- Araştırma sonucunda aile desteğinin vatandaşlık eğitimi açısından önemli olduğu sonucuna ulaşılmıştır. Öğretmenler vatandaşlık eğitiminde aile katılımı sağlanacak etkinlikler yapılmalıdır.

- Araştırmada öğretmenler vatandaşlık eğitimi konusunda eğitim gereksinimi duyduklarını ifade etmişlerdir. Bu nedenle, öğretmenlere vatandaşlık eğitimi konusunda hizmet içi eğitim verilmelidir.

- Bu araştırma derse yönelik görüşleri ortaya koymak amacıyla yapılmıştır. Bu nedenle, daha derinlemesine bilgiler elde etmek amacıyla durum çalışması deseninde araştırmalar tasarlanabilir.

- $\quad \mathrm{Bu}$ araştırmada öğretmen ve öğrencilerin görüşleri ele alınmıştır. Bu nedenle, öğrencilerin yeterlilikleri kazanıp kazanmadığına ilişkin nicel araştırmalar yapılabilir.

\section{Kaynakça}

Acun, İ., Demir, M. ve Göz, N. L. (2010). Öğretmen Adaylarının Vatandaşlık Yeterlilikleri ile Eleştirel Düşünme Becerileri Arasındaki îlişki. Journal of Social Studies Education Research, 1(1), 107123.

Acun, i., Yücel, C., Önder, A. ve Tarman, B. (2013). Değerler: Kim Ne Kadar Değer Veriyor? Uşak Üniversitesi Sosyal Bilimler Dergisi, 6 (1), 194-196.

Akar, C. (2016). Investigating the Students' Perceptions of the Democratic Values of Academicians. Journal of Social Studies Education Research, 7(1), 96-139.

Arıkan, F. (2002). Vatandaşlık ve insan Hakları Eğitimi Dersi Programının Öğretmen Görüşleri Doğrultusunda Değerlendirilmesi. (Yayımlanmamış yüksek lisans tezi). Sakarya Üniversitesi, Sosyal Bilimler Enstitüsü, Sakarya.

Bağlı, M. T. (2013). Ara-disiplin Olarak Vatandaşlık Ve İnsan Hakları Eğitimi: Illköğretim Öğrencilerinin İnsan Haklarına İlişkin Görüşleri. Eğitim ve Bilim, 38(169), 296-310.

Balbağ, N. L. ve Gürdoğan Bayır, Ö. (2016). Etkili Vatandaşlık ve Çatışma Çözme Becerisi. Ĕğtim Bilimlerinde Yenilik ve Nitelik Arayışı, İçinde (ss.915-934). Ankara: Pegem Akademi.

Balbağ, N. L. (2016). İlkokul Sosyal Bilgiler Dersi Bağlamında Öğrenci ve Öğretmenlerin Küresel Vatandaşlık Algıları. (Yayımlanmamış doktora tezi). Anadolu Üniversitesi, Eğitim Bilimleri Enstitüsü, Eskişehir. 
Baştürk, N. (2011). Illköğretim 8. Sınıf Vatandaşlık ve Demokrasi Eğitimi Dersi Öğretim Programı Kazanımlarının Öğrenci Görüşlerine Göre Değerlendirilmesi. (Yayımlanmamış yüksek lisans tezi). Atatürk Üniversitesi, Eğitim Bilimleri Enstitüsü, Erzurum.

Birzéa, C., Kerr, D., Mikkelsen, R., Froumin, I., Losito, B., Pol, M., Sardoc, M., Harrison, C. ve Baumgartl, B. (2004). All-European study on education for democratic citizenship policies. http://www.coe.int/T/E/Com/Files/Themes/ECD/-34k adresinden 15.04.2005 tarihinde alınmıştır.

Branson, M. S. (1998). The Role of Civic Education. http://www.civiced.org/articles_role.html adresinden, 01.07.2004 tarihinde alınmıstır.

Center for Civic Education [CCE]. (1997). National Standards for Civics and Government. (Second Printing). California: Center for Civic Education.

Department for Education and Skills [DfES]. (2004). A CPD Handbook: Making Sense of Citizenship. http://www.citizenshipfoundation.org.uk/lib-res-pdf/0193.pdf. adresinden $\quad 01.10 .2006$ tarihinde alınmıştır.

Elkatmış, M. (2012). İnsan Hakları ve Vatandaşlık Ara Disiplini Kazanımlarının Gerçekleşme Düzeyi. Akademik Bakış Dergisi, 29, 1-20.

Ersoy, A. F. (2007). So s ya I bilgiler de rs inde ö ğre tme nle rin e tkili va ta nda șlık e ğitimi uygula ma la rına iliş kin gö rüş le ri. Eskişehir: Anadolu Üniversitesi Yayınları.

Ersoy, A. F. (2012). Vatandaşlık Eğitiminde İhmal Edilen Bir Alan: Evde ve Okulda Çocuk Haklarının Eğitimi. International Online Journal of Educational Sciences, 4(2), 359-376.

Ersoy, A. F. (2014). Active and Democratic Citizenship Education and Its Challenges in Social Studies Classrooms. Eurasian Journal of Educational Research, 55, 1-20.

Ersoy, A. F. (2016). Fenonemoloji. A. Saban ve A. Ersoy (Eds). Eğitimde Nitel Araştırma Desenleri içinde (ss.51-105). Ankara: Anı Yayıncılık.

Ersoy, A. F. (2016). Vatandaşlık ve Demokrasi Eğitimi Dersine Illişkin Sosyal Bilgiler Öğretmenleri ve Öğrencilerinin Algısı. Inönü Üniversitesi Eğitim Fakültesi Dergisi, 17(13), 67-83.

Gömleksiz, M. N. ve Akyılız, S. (2012). Vatandaşlık ve Demokrasi Eğitimi Dersi Öğretim Programının Uygulamadaki Etkililiğinin Değerlendirilmesi. Milli Eğitim, 41(196), 69-92.

Göz, N. L. (2010). Illköğretimde Demokrasi ve Vatandaşlık Eğitimi. (Yayımlanmamış yüksek lisans tezi). Uşak Üniversitesi, Uşak.

Güdücü, H. S. (2008). Illköğretim Programlarında Yer Alan Vatandaşlık ve Insan Hakları Eğitimi Dersine ilişkin Öğretmen Algısına Yönelik Manisa Örneği. (Yayımlanmamış yüksek lisans tezi). Celal Bayar Üniversitesi, Manisa.

Gürdoğan Bayır, Ö., Göz, N. L. ve Bozkurt, M. (2014). Sınıf Öğretmeni Adaylarına Göre Sosyal Bilgiler Dersinde Küresel Vatandaşlık. Eğitim Bilimleri Araştırmaları Dergisi, 4(2), 145-162.

Güven, S. ve Şahin, İ. F. (2010). Vatandaşlık ve İnsan Hakları Egitimi Dersi Öğretmenlerinin Nitelikleri ve Karşılaştıkları Problemler: Erzincan İli Örnegi, Doğu Coğrafya Dergisi, 10, 213-226.

Güven, S., Tertemiz, N., ve Bulut, P. (2009). Vatandaşlık ve Vatandaşlık Eğitimine Yönelik Sınıf Öğretmenlerinin Görüşleri. Karadeniz Sosyal Bilimler Dergisi, 1, 149.

Kamber, T., Acun, ì. ve Akar, C (2011). İlköğretim Birinci Kademe Sosyal Bilgiler Öğretim Programının Uygulanabilirliği. Uşak Üniversitesi Sosyal Bilimler Dergisi, 4(2), 195-218.

Karaman Kepenekçi, Y. (2005). A Study of Effectiveness of Human Rights Education in Turkey. Journal of Peace Education, 2(1), 39-55.

Katılmış, A., Ekşi, H. ve Öztürk, C. (2010). Sosyal Bilgiler Dersi Kazanımlarıyla Bütünleştirilmiş Bilimsellik Odaklı Karakter Eğitimi Programının Etkililiği, Journal of Social Studies Education Research, 1(1), 50-87. 
Kaya, B. ve Ersoy, F. (2014). Vatandaşlık ve Demokrasi Eğitimi Dersinin Sekizinci Sınıf Öğrencilerinde Vatandaşlık Algısının Oluşması ile İlişkisi. Dicle Üniversitesi Ziya Gökalp Eğitim Fakültesi Dergisi, 2, 252-303

Kaymakçı, S., Öztürk, M, Palancı, M. ve Kırpık, C. (2015). İlkokul Öğretmenlerinin Gözünden Demokrasi ve İnsan Hakları Eğitimi M. Öztürk, A. Saydam ve M. Palancı (ed.). Demokrasi, Yurttaşlık ve Insan Hakları Eğitimi IIlkokul 4. Sınıf için Etkinlik Örnekleri içinde (ss. 19-49). 1. Basım Kayseri: Orka matbaa. http://hre.erciyes.edu.tr/ek web.pdf adresinden 25.04.2016 tarihinde alınmıştır.

Kerr, D. (1999). Citizenship Education in the Curriculum: An International Review. School Field, 10(3/4), http://www.ibe.unesco.org/fileadmin/user_upload/Curriculum/SEEPDFs/kerr.pdf adresinden 15.03.2014 tarihinde alınmıştır.

MEB (2015). Hayat Bilgisi Programı, Ankara: Milli Eğitim Basımevi.

MEB (2005). Sosyal Bilgiler Programı 4-5. Sınıflar, Ankara: Milli Eğitim Basımevi.

Morris, P. \& Cogan J. (2001). A Comparative Overview: Civic Education Across Six Societies. International Journal of Educational Research, 35, 109-123.

Patrick, J. (1999). Education for Constructive Engagement of Citizen in Democratic Civil Society. C. Bahmueller \& J. Patricck (eds). Principles and Practices for Democratic Citizenship (Bloomington, Indiana, ERIC Claringhouse). http://files.eric.ed.gov/fulltext/ED434866.pdf adresinden alın mıştır.

Sağlam, H. İ. ve Hayal, M. A. (2015). Sınıf Öğretmenlerinin "Insan Hakları, Yurttaşlık, ve Demokrasi” Dersinin İlkokul 4. Sınıfta Yer Almasına İlişkin Görüşleri. Abant İzet Baysal Üniversitesi Eğitim Fakültesi Dergisi, 15(1), 207-217.

Senemoğlu, N. (2007). Gelişim öğrenme ve öğretim kuramdan uygulamaya, Ankara: Gönül Yayıncılık.

Tarman, B. ve Kuran, B. (2014). Vatandaşlık Ve Demokrasi Eğitimi Dersindeki Değerlerin Öğrenilme Düzeyleri ile Çevre iliş̧kisi Hakkında Öğretmen Görüşleri. Gazi Eğitim Fakültesi Dergisi, 34(2), 293-319.

Toraman, Ç. (2012). İlköğretim Sekizinci Sınıf Vatandaşlık ve Demokrasi Eğitimi Ders Programının (2010) Değerlendirilmesi. (Yayımlanmamış yüksek lisans tezi.) Ankara Üniversitesi, Ankara.

Torney-Purta, J. ve Vermeer, S. (2004). Developing Citizenship Competencies from Kindergarten Through Grade 12: A background paper for policymakers and educators. http://www.ecs.org/html/projectsPartners/nclc/docs/DevelopingCompetencies.pdf adresinden 12.10.2005 tarihinde alınmıştır.

Torney-Purta, J., Lehaman, R, Oswald, H. \& Schulz, W. (2001). Citizenship and Education in TwentyEight Countries: Cvic knowledge and engagement at age fourteen. http://www.iea.nl/fileadmin/user_upload/Publications/Electronic_versions/CIVED_Phase2_Ag e_Fourteen.pdf adresinden 15.072016 tarihinde alınmıştır.

Ulusoy, K. ve Erkuş, B. (2016). İlkokul 4. sınıfta "İnsan Hakları, Yurttaşlık ve Demokrasi” Dersinin Okutulmasına ïlişkin Sınıf ve Sosyal Bilgiler Öğretmenlerinin Görüşlerinin incelenmesi. Adıyaman Üniversitesi Sosyal Bilimler Enstitüsü Dergisi, 8(24), 1143-1172.

Uyangör, N. (2008). İlköğretim 7. Sınıf Vatandaşlık ve İnsan Hakları Eğitimi Programının Değerlendirilmesi. Balıkesir Üniversitesi Sosyal Bilimler Enstitüsü Dergisi, 11(20), 68-95.

Ülger, M. ve Yel, S. (2013). Ara Disiplin Alanı Olarak İnsan Hakları ve Vatandaşlık Eğitimi ile İlgili Illköğretim Öğretmenlerinin Yeterlik Algıları. Uluslararası Avrasya Sosyal Bilimler Dergisi, 4(10), 19-32. 


\section{Extended Summary}

Citizenship education refers to the instructional process in which students are taught the knowledge, skills and values related to citizenship. Individuals who have these competencies after their citizenship education learn how to manage themselves in a democratic society. Different practices have been implemented with respect to citizenship education in Turkey. One of these practices is the course "Human Rights, Citizenship and Democracy" that began to be delivered to elementary fourth graders as of the 2015-2016 school year. In addition to presenting conceptual knowledge, the course aims to teach basic values related to human rights, citizenship and democracy. Another aim of the course is to enable students to turn this knowledge and values into a lifestyle and culture. In the contents of the course "Human Rights, Citizenship and Democracy", subjects such as "anthropocentrism", "active citizenship", "peace", "consensus", "pluralism", "living together", "diversity" and "superiority of law" come to the fore. In the basic approach of the curriculum, statements such as "to one's own", "to others" and "to what belongs to us" are highlighted. The curriculum consists of six units that are (1) Being Human, (2) Rights, Freedom and Responsibilities, (3) Justice and Equality, (4) Consensus, (5) Rules, and (6) Living Together. In the curriculum, teachers are asked to present the subjects through stories. Identifying students' and teachers' experiences and perceptions of the course is of significance in terms of revealing its effectiveness. The aim of this study was to examine students and teachers' experiences and perceptions of the course "Human Rights, Citizenship and Democracy".

The study was conducted by adopting qualitative research method. Phenomenological design that is one of the qualitative research designs was employed in the study. The participants were selected through the maximum diversity sampling technique. Maximum variation sampling is based on the variety of the areas examined and individuals participated, and enables representing many individuals from a large group. By means of this sampling method, readers can form an interaction between them and the study, and better interpret the research data. In this respect, the study was conducted in three elementary schools where students with low, middle and high socioeconomic status study in the Eskisehir province. A total of eight teachers and 20 students participated in the study. Semi-structured interview technique was employed, and in the interviews, students and teachers were asked about their overall views on the course "Human Rights, Citizenship and Democracy", contents of the course, subjects that the students enjoy and have difficulty in, activities implemented in the classes, assessment of student outcomes, problems experienced and suggestions. Thematic analysis was employed in the analysis of the data. Because the questions were prepared in a way that relates to the elements of the curriculum and the themes were formed in this regard, thematic analysis was preferred. In data analysis, the teachers' and students' views were compared, and the similarities and differences in their views were indicated. Maxqda qualitative data analysis program was used.

The themes including the function of the course, contents, stories/selection of stories, instructional process, assessment, problems and suggestions were formed. As a result, the teachers' and students' views that the course positively changed students' attitudes towards democracy and human rights, and they learned basic knowledge and values related to democracy and citizenship show that they evaluated the course as functional. In this context, the teachers' and students' attitudes towards the course were mostly positive, and in the direction that it was necessary. However, the teachers and students were observed to evaluate the course only in the context of values. The contents of the course focused merely on democratic values. It was insufficient in terms of evaluating political and social events and citizenship knowledge in accordance with the students' age. In addition, since there were contents only in the national scale, the global dimension was neglected.

The results showed that the teachers and students perceived the course as the Turkish course. The teachers stated that after reading the stories in the classes, they highlighted the unknown 
vocabulary and solved questions related to the texts. Adopting an instructional model that is merely based on stories in the learning and teaching process is not adequate for effective instruction and student-centred learning. Many methods apart from stories and case studies can be employed in citizenship education. The teachers mostly stated negative attitudes regarding the coursebook and the stories included in it, and they did not find these stories functional. While the teachers criticised the stories including in the coursebook due the length, abstractness and level of the texts as well as the abundance of unknown vocabulary, the students said they liked the stories. A few students stated that they could not understand the stories and they contained violence. In this course, the teachers were observed to mostly use traditional methods in assessing student outcomes. Considering that the basic values of democracy are taught in the course in overall, it can be argued that this assessment is not adequate. As a result, as for the function of this course, the majority of the basic democratic values that the curriculum focused on were acquired by the students. For this reason, this course should continue to be delivered by improving it and addressing its deficiencies. The fact that the problems revealed in the study such as the lack of conceptual education and practice, teacher incompetence, assessment approaches, inadequacy of contents, traditional teacher-centred education, and lack of coursebook and materials are consistent with the results of the studies conducted before shows that the quality and effectiveness of the citizenship education courses have not improved with the changes in the curriculum. This shows that how the citizenship course is delivered is as important as its place in the curriculum. From this perspective, it is seen that for an effective citizenship education, it should be included in all grades of elementary education as a compulsory and separate course, and be conducted with competent teachers as well as an effective curriculum and instructional materials. For this purpose, it can be suggested that the course should be delivered in accordance with students' level and by making the subjects concrete, different instructional methods and techniques should be employed, the contents of the curriculum should be re-organised by establishing a balance between the knowledge, skills and values of citizenship, and the stories covered in the course should be revised. Additionally, enhancing teachers' competence regarding democracy, human rights and citizenship education is of significance for the effectiveness of the course. 